\title{
Pencapaian Kemampuan Pemecahan Masalah Matematik Siswa SMP dengan Pendekatan Open Ended
}

\author{
Risma Amelia ${ }^{1 *}$, Siti Chotimah ${ }^{2}$ \\ 1,2 IKIP Siliwangi \\ *risma.gembil@gmail.com
}

Diterima: Oktober 2019. Disetujui: Desember 2019. Dipublikasikan: Januari 2020

\begin{abstract}
ABSTRAK
Tujuan dari penelitian ini adalah untuk menelaah pencapaian kemampuan pemecahan masalah matematik siswa SMP yang pembelajarannya menggunakan pendekatan open ended. Subjek penelitian ini adalah seluruh siswa SMP kelas VIII yang ada di Kabupaten Bandung, sebagai sampelnya ialah salah satu sekolah yang ada di Kabupaten Bandung, kelas VIII A sebagai kelas eksperimen yang memperoleh perlakuan dengan pendekatan open ended dan kelas VIII B sebagai kelas kontrol yang mendapatkan perlakuan dengan pendekatan saintifik. Metode penelitian yang digunakan yaitu metode kuasi eksperimen dengan desain pretes and postes. Instrumen yang digunakan dalam penelitian ini berupa tes kemampuan pemecahan masalah matematik berjumlah 5 butir soal uraian. Data diperoleh dari hasil pretes dan postes kemudian diolah dengan menggunakan software microsof excel. Hasil penelitian menunjukan bahwa pencapaian kemampuan pemecahan masalah matematik siswa yang pembelajarannya menggunakan pendekatan open ended lebih baik dibandingkan dengan yang pembelajarannya menggunakan pendekatan saintifik

Kata kunci: kemampuan pemecahan masalah, pendekatan open ended, pendekatan saintifik.
\end{abstract}

\begin{abstract}
The aim of this study is to examine the achievement of mathematical problem-solving abilities of junior high school students whose learning uses the open-ended approach. The subjects of this study were all eighth-grade junior high school students in Bandung regency, the sample was one of the schools in Bandung regency, class VIII A as an experimental class that received treatment with an open-ended approach and class VIII B as a control class that received treatment with a scientific approach. The instrument used in this study was in the form of a test of mathematical problem-solving abilities totaling 5 items of description items. Data obtained from the results of the pretest and posttest are then processed using Microsoft Excel software. The results showed that the achievement of students' mathematical problemsolving abilities for learning using the open-ended approach was better than learning using the scientific approach.
\end{abstract}

Keywords: problem solving abilities, open ended approach, scientific approach.

How to Cite: Amelia, R. \& Chotimah, S. (2020). Pencapaian Kemampuan Pemecahan Masalah Matematik Siswa SMP dengan Menggunakan Pendekatan Open Ended dan Saintifik. Journal of Medives: Journal of Mathematics Education IKIP Veteran Semarang, 4(1), 173-180. 


\section{PENDAHULUAN}

Masalah merupakan kata yang sudah familiar dalam keseharian siswa terlebih saat belajar. Cara seseorang menyikapi suatu masalah bergantung kepada pengetahuan dan kemampuannya dalam memecahkan masalah. Sesuai dengan Sumartini (2016), kemampuan siswa diasah melalui masalah, sehingga siswa mampu meningkatkan berbagai kompetensi yang dimilikinya. Dalam memecahkan masalah diasah juga kreativitasnya, maka dari itu masalah di matematika merupakan suatu persoalan yang mesti terselesaikan atau dipecahkan dengan menggunakan prosedur penyelesaian soal non rutin yang mana langkah penyelesaiannya harus diolah sendiri oleh siswa.

Berdasarkan hasil penelitian yang dilakukan oleh (Tomo, Yusmin, \& Riyanti 2016) menunjukan bahwa masih rendahnya kemampuan dari 33 siswa dalam menguasai pertanyaan terutama pada salah satu indikator menyusun rencana permasalahan terhitung kurang dengan persentase $31,6 \%$; kemampuan siswa dalam menyelesaikan sesuai rencana tergolong rendah dengan persentase $18,2 \%$; dan kemampuan siswa dalam memeriksa kembali prosedur dan hasil penyelesaian tergolong rendah dengan persentase $16,4 \%$, perihal rendahnya tingkat berpikir siswa dalam pemahaman konsep serta kurangnya kecerdasan memerlukan gagasan geometri dalam mengatasi masalah matematika yang berkaitan dengan bangun datar, siswa tidak mampu membangun pengetahuan matematika melalui pemecahan masalah. Data tersebut menjadi bahan acuan penulis dalam menganalisis kemampuan pemecahan masalah dalam penelitian ini.

Berdasarkan hasil wawancara murid dengan kemampuan tinggi sedang dan rendah, siswa secara keseluruhan belum mampu memahami masalah pada kalimat soal dan tidak terbiasa dengan soal cerita serta belum dapat mengidentifikasinya. Sejalan dengan (Windari, Dwina, \& Suherman, 2014) siswa kesulitan saat memecahkan permasalahan karena kurang terbiasanya mengerjakan soal kemampuan pemecahan masalah.

Widodo (2013) berpendapat pemecahan masalah menjadi hal terpenting untuk diterapkan kepada siswa pada proses pembelajaran matematika, agar tidak kehilangan makna, konsep dan prinsip yang mudah diaplikasikan pada pemecahan masalah. Sejalan dengan Tanjung (2018) pemecahan masalah penting bagi siswa maka dari itu dalam pembelajaran matematika siswa dituntut untuk berpartisipasi aktif dan berperan secara penuh dalam pembelajaran. Menurut Sumartini (2018) pemecahan masalah yakni keadaan siswa dalam menghadapi masalah-masalah untuk meraih tujuan yang diinginkan dalam penyelesaiannya, sehingga kemampuan pemecahan masalah sangat diperlukan siswa agar terselesainya soal-soal berbasis masalah. Hal itu sesuai dengan tujuan matematika menurut Winarni dan Harmini (Widodo dan Kartikasari 2017) maksud belajar matematika yang tercantum di kurikulum mata pelajaran matematika sekolah pada seluruh tingkatan pendidikan, merupakan berorientasi pada kemampuan siswa pada pemecahan masalah yang ditemui dalam aktivitas sehari-hari. Berdasarkan 
temuan-temuan di atas penulis menyimpulkan betapa pentingnya kemampuan pemecahan masalah bagi siswa.

Melihat bahwa pentingnya kemampuan pemacahan masalah yang memberikan dampak pengaruh besar pada pembelajaran maka perlu dirancang suatu pembelajaran yang dapat tercapainya kemampuan pemecahan masalah matematik terhadap siswa yaitu pendekatan open ended dimana open ended dimulai dengan masalah terbuka yang penyelesainya bisa terselesaikan dengan kemampuan atau pemahaman yang dimiliki siswa maka akan membuat siswa tertarik untuk menyelesaikan persoalan yang diajukan. Becker \& Shimada (1997) menyebutkan bahwa open-ended adalah pembelajaran yang diformulasikan untuk menyajikan masalah terbuka dengan penyelesaian atau jawaban betul lebih dari satu. Alamiah, \& Afriansyah (2018) berpendapat bahwa open ended memberikan peluang terhadap siswa agar bertambahnya pengetahuan atau pengalamannya sendiri sesuai kemampuannya dalam menemukan, memperoleh dan mengenali masalahnya. Koriyah dan Harta (2015) bahwa Pendekatan open-ended memberi kesempatan pada peserta didik untuk mendapat gagasan atau pengalaman menemukan, mengetahui dan memecahkan masalah dengan berbagai jalan keluar penyelesaian. Diharapkan dengan pemberian soal-soal open ended serta pembelajaran yang berbasis open ended akan membuat siswa berpikir terbuka dengan beragam strategi yang ia miliki akan menerima suatu hasil akhir berupa pemecahan masalah yang diberikan. Menurut Desiyani (2018) pendekatan Open-ended ini, siswa dituntut mengerjakan sesuai kemampuannya dan pemikirannya sendiri, tidak terpaku pada aturan atau rumus yang ada Menurut Nohda (Trianto, 2013) tujuan pengajaran pendekatan open ended yaitu membantu pengembangan keaktifan kreatifitas siswa dari kemampuan berpikir matematik mereka dalam pemecahan masalah karena mengingat rendahnya memahami masalah maka akan cocok dengan open ended dimana salah satu langkah awal pada pembelajaran diawali memberikan masalah terbuka. Langkah-langkah pembelajaran open ended di antaranya menurut Hidayat dan Sariningsih (2018) adalah: (a) guru memberikan masalah kepada siswa, (b) siswa mengeksplor permasalahan yang diberikan guru, (c) guru mencatat respon siswa, (d) pembahasan respon siswa di kelas, (e) siswa merangkum yang telah dipelajari.

Adapun persoalan terbuka dijelaskan ke dalam 3 bagian keterbukaan Becker \& Epstein (Aras, 2018) yaitu: (1) proses terbuka (open process), ada banya cara untuk sampai pada solusi dari masalah, (2) masalah open-ended (openended problems), masalah dapat memiliki beberapa jawaban benar, (3) dari masalah untuk masalah (from problem to problem) siswa menggambarkan dengan pikiran mereka sendiri untuk merumuskan masalah baru. Berdasarkan uraian diatas maka penelitian ini bertujuan untuk menganalisis kemampuan pemecahan masalah dengan penggunaan open ended serta memberikan informasi pelajaran yang didapat sehingga dapat meningkatkan kemampuan pemecahan masalah. Merujuk ke kurikulum yang 
diterapkan sebagian besar pembelajaran di sekolah sudah menggunakan pendekatan saintifik. Oleh karena itu penulis dengan desain penelitian eksperimen menggunakan dua kelas sebagai subjek penelitian, kelas eksperimen dengan menerapkan pendekatan open ended dan kelas kontrol dengan pendekatan saintifik.

Oleh karena itu, rumusan masalah penelitian ini apakah kemampuan pemecahan masalah siswa SMP yang menggunakan pendekatan open ended lebih baik daripada yang menggunakan pendekatan saintifik.

\section{METODE PENELITIAN}

Metode yang dipakai adalah kuasi eksperimen, dengan 2 kelas yang digunakan sebagai kelas eksperimen dan kelas kontrol. Instrumen penelitian ini mencakup 4 indikator dengan 5 soal kemampuan pemecahan masalah. Indikator yang digunakan yaitu indikator kemampuan pemecahan masalah menurut Sumarmo (2014) (1) mengidentifikasi kelengkapan data untuk memecahkan masalah, (2) membuat metode matematika dari sesuatu masalah dan menyelesaikannya, (3) memilih serta penerapan rencana untuk mengatasi masalah atau di luar matematika, (4) menginterpretasikan hasil seperti permasalahan asal serta mengecek keabsahan jawaban.

Pada kuasi eksperimen, menurut Ruseffendi, subjek tidak dikelompokan secara acak, tetapi peneliti menerima keadaan subjek seadanya.

Desain yang digunakan penelitian ini adalah sebagai berikut.

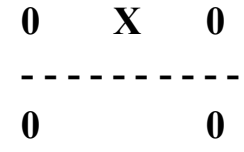

(Ruseffendi, 2010).

Keterangan:

- - : Pengambilan sampel tidak secara acak subjek

0 : Pretes = Postes (kemampuan pemecahan masalah)

$\mathrm{X}$ : Pembelajaran dengan menggunakan pendekatan open ended

Populasi penelitian ini adalah semua siswa kelas VIII SMP disalah satu sekolah di Kabupaten Bandung, sedangkan sampelnya yang dipilih dua kelas oleh pihak sekolah dari seluruh kelas VIII yaitu kelas VIII A sebagai kelas eksperimen dan VIII B sebagai kelas kontrol.

\section{HASIL PENELITIAN DAN PEMBAHASAN}

Data pretes postes dilakukan menggunakan statistik deskriptif, hal ini akan menjawab rumusan masalah tersebut dilakukan perhitungan data skor pretes dan postes kemampuan pemecahan masalah matematik di kelas eksperimen dan kontrol. Langkah pertama yang dilakukan untuk kedua kelas yang dijadikan sampel yaitu pemberian soal pretes, yang bertujuan untuk membaca permulaan kemampuan pemecahan masalah matematik siswa setara atau tidak. Setelah dilakukan pretes pada kelas eksperimen dan kontrol maka dilakukan pengujian berbantuan SPSS 16 menggunakan uji statistic Shapiro-Wilk dengan taraf signifikansi 0,05. Pretes diolah dengan uji 
nonparametrik mann whitney dikarenakan 2 kelas tidak berdistribusi normal.

Uji Mann Whitney dilakukan untuk mengetahui perbedaan kemampuan pemecahan masalah matematik siswa kelas eksperimen dan kelas kontrol. Sehingga pengujian hipotesis dilakukan dengan uji statistic non parametric Mann Whitney. Hipotesis statistik dalam pengujian ini dirumuskan sebagai berikut.

$\mathrm{H}_{0}: \mathrm{X}=\mathrm{Y}$

(Tidak terdapat perbedaan kemampuan awal pemecahan masalah matematik siswa yang menggunakan pendekatan open ended dan pendekatan saintifik.)

$\mathrm{H}_{\mathrm{a}}: \mathrm{X} \neq \mathrm{Y}$

(Terdapat perbedaan kemampuan awal pemecahan masalah matematik siswa yang menggunakan pendekatan open ended dan pendekatan saintifik.)

Keterangan :

$\mathrm{X}$ : Kemampuan pemecahan masalah matematik kelas eksperimen

Y: Kemampuan pemecahan masalah matematik kelas kontrol

Sedangkan kriteria pengujiannya adalah sebagai berikut.

Jika $p$-value $\leq 0,05$ maka $\mathrm{H}_{0}$ ditolak.

Jika $p$-value $>0,05$ maka $\mathrm{H}_{0}$ diterima.

Tabel 1. Hasil Uji Mann-Whitney Data Pretes Kemampuan Pemecahan Masalah

\begin{tabular}{cc}
\hline \multicolumn{2}{c}{ Pretes } \\
\hline Mann-Whitney U & 412.5 \\
Wilcoxon W & 940.5 \\
Z & -1.339 \\
Asymp. Sig. (2-tailed) & 0.180 \\
\hline
\end{tabular}

Berdasarkan Tabel 1 dapat dilihat bahwa nilai signifikansi (2-tailed) adalah 0,180 yang berarti $>0,05$ maka $\mathrm{H}_{0}$ diterima, sehingga berkesimpulan bahwa pada kedua kelas baik kelas eksperimen ataupun kelas kontrol tidak terdapat perbedaan kemampuan awal pemecahan masalah matematik siswa.

Setelah pretes selesai dilakukan, pada kelas eksperimen siswa mendapat perlakuan pendekatan open ended dan kelas kontrol dengan pendekatan saintifik. Pertemuan dilakukan sebanyak 6 kali tatap muka. Tahap terakhir siswa diberikan soal postes agar mengetahui kemampuan pemecahan masalah matematik siswa setelah perlakuan. Hasil analisis soal postes disajikan pada tabel 2 dibawah ini, dengan hipotesis sebagai berikut.

\section{$\mathrm{H}_{0}: \mathrm{X} \leq \mathrm{Y}$}

(Kemampuan pemecahan masalah matematik yang menggunakan pendekatan open ended tidak lebih baik dari pada yang menggunakan pendekatan saintifik)

$\mathrm{H}_{\mathrm{a}}: \mathrm{X}>\mathrm{Y}$

(Kemampuan pemecahan masalah matematik yang menggunakan pendekatan open ended lebih baik dari pada yang menggunakan pendekatan saintifik)

Keterangan :

$\mathrm{X}$ : Kemampuan pemecahan masalah matematik kelas eksperimen

Y: Kemampuan pemecahan masalah matematik kelas kontrol

Sedangkan kriteria pengujiannya adalah sebagai berikut.

Jika $p$-value $\leq 0,05$ maka $\mathrm{H}_{0}$ ditolak. Jika $p$-value $>0,05$ maka $\mathrm{H}_{0}$ diterima. 
Tabel 2. Uji Mann Whitney Data Postes Kemampuan Pemecahan Masalah

\begin{tabular}{|c|c|c|c|}
\hline \multicolumn{4}{|c|}{ Postes } \\
\hline \multicolumn{3}{|c|}{ Mann-Whitney U } & 331.000 \\
\hline \multicolumn{3}{|c|}{ Wilcoxon W } & 859.000 \\
\hline \multicolumn{3}{|c|}{ Z } & -2.432 \\
\hline \multirow{3}{*}{$\begin{array}{l}\text { Monte } \\
\text { Carlo } \\
\text { Sig. (1- } \\
\text { tailed) }\end{array}$} & $95 \%$ & Lower Bound & .005 \\
\hline & $\begin{array}{l}\text { Confidence } \\
\text { Interval }\end{array}$ & Upper Bound & .008 \\
\hline & & Sig. & $.005^{\mathrm{a}}$ \\
\hline
\end{tabular}

Analisis data postes yang dilakukan adalah uji satu pihak monte carlo (1tailed) dengan nilai signifikansinya yaitu 0,05 . Karena nilai signifikansi 0,005 maka berdasarkan kriteria uji perbedaan dua rata-rata $\mathrm{H}_{0}$ ditolak. Sehingga hal ini menunjukan bahwa kemampuan pemecahan masalah matematik siswa SMP kelas eksperimen yang menerapkan pembelajaran open ended lebih baik dari pembelajaran saintifik.

Berdasarkan hasil pengolahan data pretes dengan uji non parametrik mann whitney tidak terdapat perbedaan kemampuan awal pemecahan masalah matematik, tetapi setelah dilakukan treatment pendekatan open ended pada kelas eksperimen dan pendekatan saintifik pada kelas kontrol diperoleh bahwa adanya perbedaan pencapaian rata-rata kemampuan pemecahan masalah matematik siswa SMP di mana kelas eksperimen unggul dibandingkan kelas kontrol. Pencapaian skor pretes dan postes kelas eksperimen terlihat di Gambar 1.

Berdasarkan gambar 1 terlihat perbedaan dan pencapaian dari rata-rata nilai pretes dan postes siswa baik kelas eksperimen maupun kelas kontrol. Selisih rata-rata pretes dan postes kelas eksperimen yaitu 33,2 sedangkan selisih

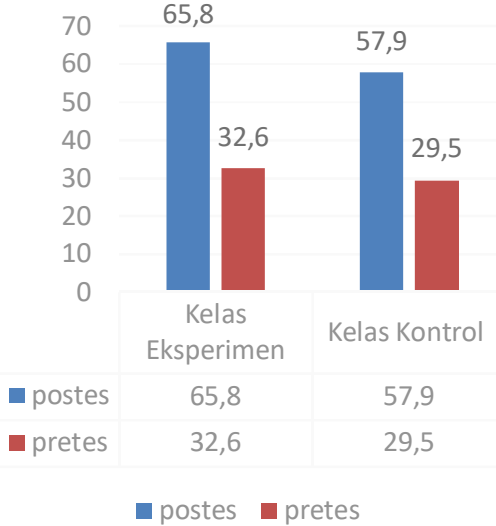

Gambar 1. Diagram Batang Pencapaian Kemampuan Pemecahan Masalah Matematik Berdasarkan Skor Pretes dan Postes

postes pretes kelas kontrol 28,4. Sehingga dapat disimpulkan bahwa kemampuan pemecahan masalah pada kelas eksperimen lebih baik daripada kelas kontrol setelah diberikan treatment pendekatan open ended, hal ini sejalan dengan analisis data secara statistik dengan menggunakan SPSS.

\section{KESIMPULAN}

Berdasarkan hasil penelitian data terhadap kemampuan pemecahan masalah matematik siswa SMP dengan mengaplikasikan pendekatan open ended dan pendekatan saintifik dapat disimpulkan bahwa kemampuan pemecahan masalah matematik siswa SMP yang menggunakan pendekatan open ended lebih baik daripada yang menggunakan pendekatan saintifik.

Adapun saran pembelajaran matematika di kelas dengan menggunakan pendekatan open ended hendaknya dijadikan sebagai salah satu alternatif pembelajaran untuk meningkatkan kemampuan pemecahan masalah matematik dan mengatasi kesulitan siswa dalam mengerjakan soal pemecahan masalah. 


\section{DAFTAR PUSTAKA}

Alamiah, U. S., \& Afriansyah, E. A. (2018). Perbandingan Kemampuan Komunikasi Matematis Siswa Antara yang Mendapatkan Metode Pembelajaran Problem Based Learning dengan Pendekatan Realistic Mathematics Education dan Open-Ended. Mosharafa: Jurnal Pendidikan Matematika, 6(2), 207-216.

Aras, I. (2018). Pendekatan open-ended dalam pembelajaran matematika. EDUKASIA: JURNAL PENDIDIKAN, 5(2), 53-62.

Becker, J. P., \& Shimada, S. (1997). The Open-Ended Approach: A New Proposal for Teaching Mathematics. National Council of Teachers of Mathematics, 1906 Association Drive, Reston, VA 20191-1593.

Desiyani, W. (2018). Pengaruh Metode Pembelajaran Core Dengan Pendekatan Open-Ended Terhadap Pemahaman Dan Kemampuan Representasi Matematis Materi Geometri Siswa Kelas Vii Di Smpn 1 Panggul Tahun Ajaran 2017/2018

Hidayat, W., \& Sariningsih, R. (2018). Kemampuan Pemecahan Masalah Matematis dan Adversity Quotient Siswa SMP Melalui Pembelajaran Open ended.JNPM (Jurnal Nasional Pendidikan Matematika), 2(1), 109-118.

Sumartini, T. S. (2016). Peningkatan kemampuan pemecahan masalah matematis siswa melalui pembelajaran berbasis masalah. Mosharafa: Jurnal Pendidikan Matematika,5(2), 148-158.
Sumartini, T. S. (2018). Peningkatan Kemampuan Pemecahan Masalah Matematis Siswa Melalui Pembelajaran Berbasis Masalah. Mosharafa: Jurnal Pendidikan Matematika,5(2), 148-158.

Sumarmo, U. (2014). Pengembangan Hard Skill dan Soft Skill Matematik Bagi Guru dan Siswa untuk Mendukung Implementasi Kurikulum 2013. In Prosiding Seminar Nasional Pendidikan Matematika Program Pasca Sarjana (pp. 4-15).

Ruseffendi, E.T.(2010). Dasar-dasar Penelitian Pendidikan dan Bidang Non-eksakta Lainnya Bagi Para Peneliti, Penulis Skripsi, Penulis Thesis, Penulis Disertasi, Dosen Metode Penelitian, dan Mahasiswa. Bandung: Tarsito.

Tanjung, H. S. (2018). Perbedaan Kemampuan Berpikir Kreatif dan Pemecahan Masalah Matematis Siswa dalam Penerapan Metode Pembelajaran Berbasis Masalah. Genta Mulia, 9(1).

Tomo, T., Yusmin, E., \& Riyanti, S (2016). Kemampuan Pemecahan Masalah Siswa pada Materi Bangun Datar di SMP. Jurnal Pendidikan dan Pembelajaran Untan, 5(5).

Trianto, (2013). Mendesain Metode Pembelajaran Inovatif Progresif. Jakarta:Kencana Prenada Media Group.

Widodo, S. A. (2013). Analisis kesalahan dalam pemecahan masalah divergensi tipe membuktikan pada mahasiswa matematika. Jurnal pendidikan dan pengajaran, 46(2 Juli). 
180 | Risma Amelia, Siti Chotimah - Pencapaian Kemampuan Pemecahan Masalah Matematik Siswa SMP dengan ....

Widodo, S., \& Kartikasari, K. (2017).

Pembelajaran Pemecahan Masalah Matematis Siswa Sekolah Dasar Dengan Model Creative Problem Solving (Cps). PRISMA, 6(1).

Windari, F. (2014). Meningkatkan Kemampuan Pemecahan Masalah Matematika Siswa Kelas Viii SMPN 8 Padang Tahun Pelajaran 2013/2014 dengan Menggunakan Strategi Pembelajaran Inkuiri. Journal Pendidikan Matematika UNP, 3(2). 